\title{
Synthesis and structure of new imidazo- and pyrazolo[5,1-d][1,2,3,5] thiatriazines based on the reaction of diazoazoles with acyl isothiocyanates controlled by $\mathrm{S} \cdots \mathrm{O}$ interaction
}

\author{
Elena V. Sadchikova ${ }^{a}$, Vasiliy A. Bakulev ${ }^{\mathrm{a}, *}$, Julia O. Subbotina ${ }^{\mathrm{a}, \mathrm{c}}$, Darya L. Privalova ${ }^{\mathrm{a}}$, \\ Wim Dehaen ${ }^{\mathrm{b}}$, Kristof Van Hecke ${ }^{\mathrm{b}}$, Koen Robeyns ${ }^{\mathrm{b}}$, Luc Van Meervelt ${ }^{\mathrm{b}}$, \\ Vladimir S. Mokrushin ${ }^{\text {a }}$ \\ ${ }^{a}$ TOS Department, Ural Federal University named after the first President of Russia B.N. Yeltsin, Mira str. 19, 620002 Yekaterinburg, Russia \\ ${ }^{\mathrm{b}}$ Department of Chemistry, University of Leuven, B-3001 Leuven, Belgium \\ ' I. Ya. Postovsky Institute of Organic Synthesis of the Ural Branch of Russian Academy of Sciences, S. Kovalevskaya Str. 20, 620219 Yekaterinburg, Russia
}

\section{A R T I C L E I N F O}

\section{Article history:}

Received 10 April 2013

Received in revised form 30 May 2013

Accepted 17 June 2013

Available online 24 June 2013

Keywords:

Cycloaddition

Diazoazoles

Thiatriazines

Nonbonded S $\cdots O$ O interaction

Covalence ratio factor

\begin{abstract}
A B S T R A C T
5-Diazoimidazoles and 5-diazopyrazoles have been shown to react with acyl isothiocyanates yielding the imidazo- and pyrazolo[5,1- $d][1,2,3,5]$ thiatriazines stabilized by a nonbonded $\mathrm{S} \cdots \mathrm{O}$ interaction. In contrast to acyl isothiocyanates, alkyl-, aryl-, and arylsulfonyl isothiocyanates do not react with 5-diazoazoles. The nature and the strength of stabilizing intramolecular interaction between non-bonded $\mathrm{S}$ and $\mathrm{O}$ atoms have been studied by X-ray analysis for mono crystals and DFT calculations for selected azolo[5,1- $d]$ $[1,2,3,5]$ thiatriazines. The interaction was described in terms of Weinhold covalence ratio factors, NBO, and AIM schemes. The reaction discovered was used to develop an efficient approach toward the new 8substituted 4-ethoxycarbonylimino-4-benzoyl- and 4-(3,4,5,6-tetrafluorobenzoyl)iminoimidazo(pyrazolo) $[5,1-d][1,2,3,5]$ thiatriazines.
\end{abstract}

(c) 2013 Elsevier Ltd. All rights reserved.

\section{Introduction}

1,3-Dipolar cycloaddition reactions of aliphatic diazo compounds to triple and double bonds are well known and documented. ${ }^{1-3}$ They have been widely used in the synthesis of various heterocyclic azoles. Thus, it is well known that an efficient and convenient method for the synthesis of 5-amino-1,2,3-thiadiazoles includes the cycloaddition reactions of alkyl and aryl isothiocyanates with aliphatic diazo compounds. ${ }^{4}$ Nevertheless, the study of the cycloaddition reactions of aliphatic diazo compounds as a model for various types of pericyclic processes continues to interest physical organic chemists. ${ }^{5-8}$

Heterocyclic diazo compounds, where the $\alpha$ carbon atom has been incorporated into the heteroaromatic system, are known to react as 1,7-dipoles with electron-rich olefins, ${ }^{9}$ acetylenes, ${ }^{1}$ and isocyanates $^{10-12}$ leading to six-membered heterocyclic compounds. In comparison with aliphatic diazo compounds, heterocyclic diazo compounds have been studied poorly. At the same time, expanding the scope of the cycloaddition reaction of

\footnotetext{
* Corresponding author. E-mail address: v.a.bakulev@ustu.ru (V.A. Bakulev).
}

heterocyclic diazo compounds as an efficient approach to fused azoles is very important for medicinal chemistry. Reactions of 5diazoazoles with isocyanates are known to take place in very mild conditions to afford azolo[5,1-d][1,2,3,5]tetrazines. Two compounds of the imidazole series $\mathbf{1 a}, \mathbf{b}$ exhibited a high level of antitumor activity and have been used in both medicinal sciences and practice (Scheme 1$).^{13-15}$<smiles>NC(=O)c1nc[nH]c1N</smiles>

$3 a$<smiles>N=C1N=CN=C1C(N)=O</smiles>

$2 a$<smiles>[R]n1nnc2c(C(N)=O)ncn2c1=O</smiles>

$1 a, b$
Scheme 1. Reactions of diazoimidazoles with isocyanates leading to mitozolomide 1a $\left(\mathrm{R}=\mathrm{CH}_{2} \mathrm{CH}_{2} \mathrm{Cl}\right)$ and temozolomide $\mathbf{1 b}\left(\mathrm{R}=\mathrm{CH}_{3}\right)$.

It is also reported that diazoimidazole $\mathbf{2 a}$ does not react with methyl isothiocyanate either in $\mathrm{Me}_{2} \mathrm{SO}$ at $40{ }^{\circ} \mathrm{C}$ or in an inert solvent containing either the Lewis acids, such as zinc iodide and boron trifluoride-etherate or triethylamine. ${ }^{16}$ The reasons for the 
different reactivity of isocyanates and isothiocyanates in their reaction with diazoazoles are not rationalized.

In a preliminary report ${ }^{17}$ we described a new cycloaddition reaction of 5-diazoazoles with benzoyl isothiocyanate leading to a few examples of novel 1,2,3,5-thiatriazines fused to imidazole and pyrazole rings. Interestingly, at the same time Ali Deeb and Mahmud Kolb published an alternative regiochemistry for the reaction of 3-diazopyrazolo[3,4-c]pyridazine with phenyl- and ethoxycarbonyl isothiocyanates, leading to 1,2,3,5-triazine-4-thione derivatives. ${ }^{18}$ These authors did not consider the possibility for formation of a 1,2,3,5-thiatriazole in this reaction. Furthermore the structures of the products prepared by these authors ${ }^{18}$ were confirmed by ${ }^{1} \mathrm{H}$ NMR spectra only, which may not be conclusive proof for such heteroatom-rich compounds. Therefore, for the better understanding of the direction of cyclization and with the aim of developing a general approach to azolo[1,2,3,5]thiatriazines we have further studied the reaction of a series of 5-diazoimidazoles and 5-diazopyrazoles, and 2-diazoimidazole-4,5-dicarbonitrile involving apart of benzoyl isothiocyanate, tetrafluorobenzoyl, phenylsulfonyl,- and ethoxycarbonyl isothiocyanates and have made a careful study of the structures of the reaction products by X-ray diffraction analysis, IR-, and NMR spectroscopy and theoretical calculations. Special attention has been paid to the factors that stabilize the reaction products because we have recently shown by calculations with Hartree-Fock and DFT methods ${ }^{19}$ that the reaction of diazo compounds $\mathbf{5}$ with acyl isothiocyanates is thermodynamically controlled.

\section{Results and discussion}

The starting 5-diazoimidazoles $\mathbf{2 b}-\mathbf{f}$ are prepared according to a modified procedure ${ }^{20-23}$ by diazotization of the corresponding amines $\mathbf{3 b}-\mathbf{f}$ in dilute hydrochloric acid with sodium nitrite at $-5{ }^{\circ} \mathrm{C}$. It is worth noting that diazotization of 5-aminopyrazoles $\mathbf{3 g}-\mathbf{j}$ under these conditions leads to the corresponding pyrazolyl-5-diazonium salts, which can be easily transformed to 5diazopyrazoles $2 \mathbf{g}-\mathbf{j}$ by treatment of the reaction mixture with $10 \%$ sodium bicarbonate solution at $\mathrm{pH} 5.5$, followed by extraction with chloroform. The diazonium salts themselves are inert in the investigated type of reactions.

In principle, both the $\mathrm{C}=\mathrm{N}$ and $\mathrm{C}=\mathrm{S}$ bonds of isothiocyanates 4 can take part in the cycloaddition reaction with diazoazoles $\mathbf{2}$ to form either 1,2,3,5-thiatriazine $\mathbf{5}$ or 1,2,3,5-tetrazine $\mathbf{6}$ or their mixture. In our preliminary report ${ }^{17}$ we have shown that both 5 diazoimidazoles $\mathbf{2 a}-\mathbf{f}$ and 5-diazopyrazoles $2 \mathbf{g}-\mathbf{j}$ do not react with methyl or phenyl isothiocyanates (Scheme 2).
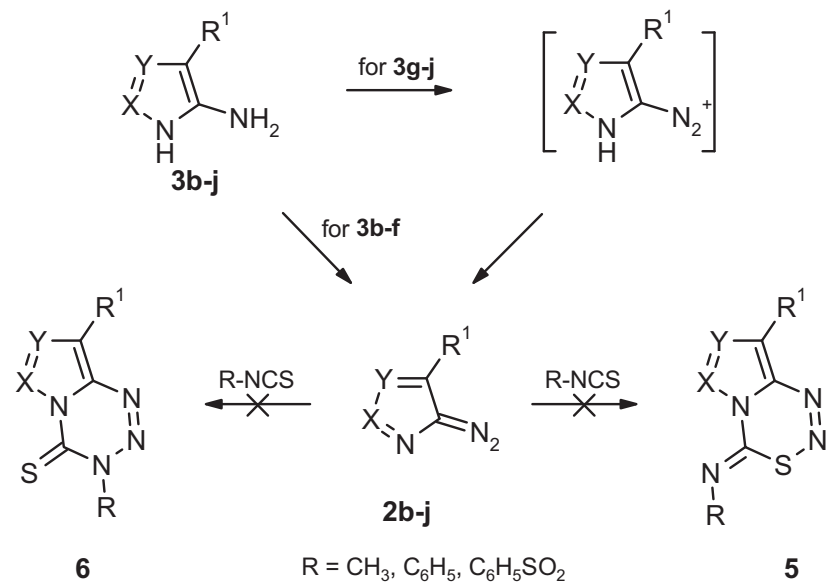

Scheme 2. Synthesis of 5-diazoazoles.
Now we have found that they also did not react with phenylsulfonyl isothiocyanate bearing a strong electron acceptor substituent. Indeed, 3-methyl-, 3-phenylsulfonyl-, and 3-phenylazolo $[5,1-d][1,2,3,5]$ tetrazine- $4(3 H)$-thiones of type 6 could not be prepared in the same way as their oxygen analogs. In contrast to the reactions with methyl- and phenyl isothiocyanate the analogous reactions of diazoazoles $\mathbf{2} \mathbf{b}-\mathbf{j}$ with isothiocyanates containing carbonyl groups, such as ethoxycarbonyl isothiocyanate $\mathbf{4 a}$, benzoyl isothiocyanate $\mathbf{4 b}$ and tetrafluorobenzoyl isothiocyanate $\mathbf{4 c}$ occur readily in solution of anhydrous ethyl acetate to give azolo[5,1-d] $[1,2,3,5]$ thiatriazines $\mathbf{5}$ as the only products (Scheme 3, Table 1 ).

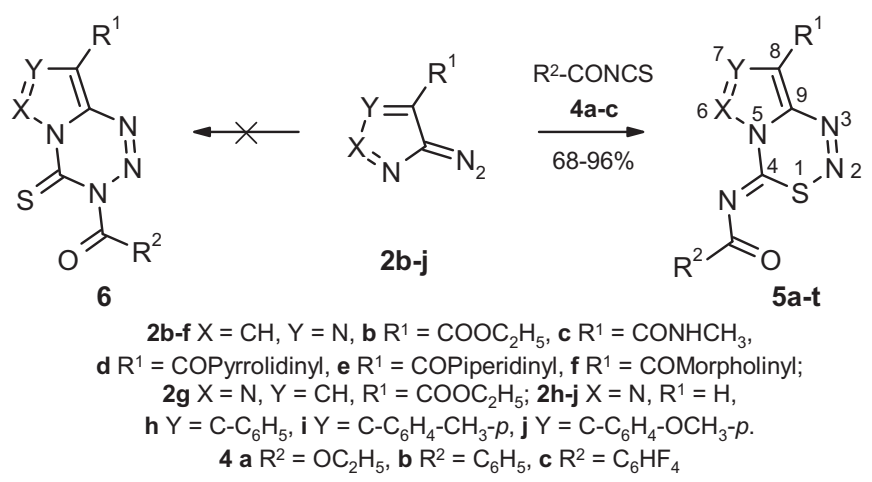

Scheme 3. Reactions of diazoazoles $\mathbf{2} \mathbf{b}-\mathbf{j}$ with acylisothocyanates $\mathbf{4 a}-\mathbf{c}$.

Table 1

Characteristics of azolo[5,1-d][1,2,3,5]thiatriazines $\mathbf{5}$

\begin{tabular}{|c|c|c|c|c|c|c|}
\hline & $\mathrm{X}$ & $\mathrm{Y}$ & $\mathrm{R}^{1}$ & $\mathrm{R}^{2}$ & Yield, \% & $\begin{array}{l}\text { Duration of } \\
\text { reaction, h }\end{array}$ \\
\hline $5 \mathbf{a}$ & $\mathrm{CH}$ & $\mathrm{N}$ & $\mathrm{COOC}_{2} \mathrm{H}_{5}$ & $\mathrm{OC}_{2} \mathrm{H}_{5}$ & 79 & 18 \\
\hline $\mathbf{5 b}$ & $\mathrm{CH}$ & $\mathrm{N}$ & $\mathrm{COOC}_{2} \mathrm{H}_{5}$ & $\mathrm{C}_{6} \mathrm{H}_{5}$ & 88 & 3.5 \\
\hline $5 c$ & $\mathrm{CH}$ & $\mathrm{N}$ & $\mathrm{CONHCH}_{3}$ & $\mathrm{OC}_{2} \mathrm{H}_{5}$ & 69 & 19 \\
\hline 5d & $\mathrm{CH}$ & $\mathrm{N}$ & $\mathrm{CONHCH}_{3}$ & $\mathrm{C}_{6} \mathrm{H}_{5}$ & 76 & 3.5 \\
\hline $5 e$ & $\mathrm{CH}$ & $\mathrm{N}$ & COPyrrolidinyl & $\mathrm{OC}_{2} \mathrm{H}_{5}$ & 70 & 20 \\
\hline $5 f$ & $\mathrm{CH}$ & $\mathrm{N}$ & COPyrrolidinyl & $\mathrm{C}_{6} \mathrm{H}_{5}$ & 68 & 4 \\
\hline $5 g$ & $\mathrm{CH}$ & $\mathrm{N}$ & COPiperidinyl & $\mathrm{OC}_{2} \mathrm{H}_{5}$ & 73 & 20 \\
\hline $5 h$ & $\mathrm{CH}$ & $\mathrm{N}$ & COPiperidinyl & $\mathrm{C}_{6} \mathrm{H}_{5}$ & 78 & 4 \\
\hline $5 \mathbf{i}$ & $\mathrm{CH}$ & $\mathrm{N}$ & COMorpholinyl & $\mathrm{OC}_{2} \mathrm{H}_{5}$ & 72 & 20 \\
\hline $5 \mathbf{j}$ & $\mathrm{CH}$ & $\mathrm{N}$ & COMorpholinyl & $\mathrm{C}_{6} \mathrm{H}_{5}$ & 81 & 4 \\
\hline $5 k$ & $\mathrm{~N}$ & $\mathrm{CH}$ & $\mathrm{COOC}_{2} \mathrm{H}_{5}$ & $\mathrm{OC}_{2} \mathrm{H}_{5}$ & 72 & 16 \\
\hline 51 & $\mathrm{~N}$ & $\mathrm{CH}$ & $\mathrm{COOC}_{2} \mathrm{H}_{5}$ & $\mathrm{C}_{6} \mathrm{H}_{5}$ & 84 & 3.5 \\
\hline $5 \mathrm{~m}$ & $\mathrm{~N}$ & $\mathrm{C}-\mathrm{C}_{6} \mathrm{H}_{5}$ & $\mathrm{H}$ & $\mathrm{OC}_{2} \mathrm{H}_{5}$ & 87 & 18 \\
\hline $5 n$ & $\mathrm{~N}$ & $\mathrm{C}-\mathrm{C}_{6} \mathrm{H}_{5}$ & $\mathrm{H}$ & $\mathrm{C}_{6} \mathrm{H}_{5}$ & 83 & 4 \\
\hline 50 & $\mathrm{~N}$ & $\mathrm{C}-\mathrm{C}_{6} \mathrm{H}_{5}$ & $\mathrm{H}$ & $\mathrm{C}_{6} \mathrm{HF}_{4}$ & 78 & 6 \\
\hline $5 p$ & $\mathrm{~N}$ & $\mathrm{C}-\mathrm{C}_{6} \mathrm{H}_{4}-\mathrm{CH}_{3}-p$ & $\mathrm{H}$ & $\mathrm{OC}_{2} \mathrm{H}_{5}$ & 96 & 15 \\
\hline $\mathbf{5 q}$ & $\mathrm{N}$ & $\mathrm{C}-\mathrm{C}_{6} \mathrm{H}_{4}-\mathrm{CH}_{3}-p$ & $\mathrm{H}$ & $\mathrm{C}_{6} \mathrm{H}_{5}$ & 98 & 3 \\
\hline $5 r$ & $\mathrm{~N}$ & $\mathrm{C}-\mathrm{C}_{6} \mathrm{H}_{4}-\mathrm{CH}_{3}-p$ & $\mathrm{H}$ & $\mathrm{C}_{6} \mathrm{HF}_{4}$ & 83 & 5 \\
\hline $5 s$ & $\mathrm{~N}$ & $\mathrm{C}-\mathrm{C}_{6} \mathrm{H}_{4}-\mathrm{OCH}_{3}-p$ & $\mathrm{H}$ & $\mathrm{OC}_{2} \mathrm{H}_{5}$ & 70 & 15 \\
\hline $5 t$ & $\mathrm{~N}$ & $\mathrm{C}-\mathrm{C}_{6} \mathrm{H}_{4}-\mathrm{OCH}_{3}-p$ & $\mathrm{H}$ & $\mathrm{C}_{6} \mathrm{H}_{5}$ & 89 & 3 \\
\hline $5 \mathbf{u}$ & $\mathrm{N}$ & $\mathrm{CH}$ & $\mathrm{COOC}_{2} \mathrm{H}_{5}$ & $\mathrm{PhSO}_{2}$ & & $\begin{array}{l}\text { Is not } \\
\text { formed }\end{array}$ \\
\hline
\end{tabular}

The method of choice involves conducting the experiment at room temperature, under an atmosphere of argon and in the absence of light. The use of other solvents increases the reaction time. On the other hand, the increase of temperature leads to the formation of tar-like products. The absence of oxygen and the protection of the reaction mixture from light diminish the decomposition of the diazoazoles that may occur via the formation of radicals. The completion of the reaction was estimated by the disappearance of the diazo compound according to IR and TLC analysis. The reaction time depends on the nature of the acyl isothiocyanates and takes 3-3.5 h for benzoyl isothiocyanate $4 \mathbf{b}, 6 \mathrm{~h}$ for tetrafluorobenzoyl isothiocyanate $4 c$ and $15-20 \mathrm{~h}$ for the less electron poor ethoxycarbonyl isothiocyanate $\mathbf{4 a}$. It should be noted that 2-diazoimidazole-4,5-dicarbonitrile is found to be inactive in 
reactions with any isothiocyanate. Because both 5-diazoimidazoles and 5-diazopyrazoles do not react neither with alkyl- and aryl isothiocyanates nor with phenylsulfonyl isocyanate in spite of the latter containing a strong electron acceptor group, we have concluded that the presence of the carbonyl group in the isothiocyanate molecules is needed for their reaction with 5diazoazoles.

The thiatriazines $\mathbf{5 a}-\mathbf{t}$ are isolated in high yields (68-98\%) (See Table 1) and gave satisfactory elemental analyses. The NMR spectra for cycloadducts $\mathbf{5 a}-\mathbf{t}$ demonstrate that all of the compounds belong to the same structural type with the same heterocyclic systems present. Thus, the ${ }^{1} \mathrm{H}$ NMR and ${ }^{13} \mathrm{C}$ NMR spectra contain signals of the substituents attached to either the azole rings or the imino group of the thiatriazine ring. As expected, for fused azoles the signal assigned to the azole proton of compounds $\mathbf{5 a}-\mathbf{s}$ is significantly shifted downfield ( $\Delta \delta=1.44-1.95$ for proton and $29 \mathrm{ppm}$ for carbon NMR spectra, respectively) compared to the diazoazole precursors $\mathbf{2 b}-\mathbf{j}$. Signals at $\delta=176-180 \mathrm{ppm}$ in compounds $\mathbf{5 b}, \mathbf{d}, \mathbf{f}, \mathbf{h}, \mathbf{j}, \mathbf{1}, \mathbf{n}, \mathbf{p}, \mathbf{,}, \mathbf{q}, \mathbf{r}, \mathbf{t}$ are assigned to the benzoyl carbon, and the

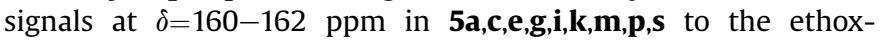
ycarbonyl carbons and this is in agreement with literature data for these groups in similar compounds. ${ }^{24,25}$

Signals at 155.1-160.8 ppm were assigned to carbons of the $\mathrm{C}_{4}=\mathrm{N}$ groups of the 1,2,3,5-thiatriazine ring based on the careful analysis for spectra of series of compounds $\mathbf{5 a}-\mathbf{s}$. The signals corresponding to $C_{9}$ of the bicycle compounds $\mathbf{5}$ were observed in broad region of 134-147 ppm depending on the substituents and nature of azole rings.

We have shown by NMR study that compounds $\mathbf{5}$ are not stable in the presence of water and alcohols therefore all NMR measurements were made just after the samples were dissolved.

It is worth noting that all spectroscopic data are in good agreement with both thiatriazine $\mathbf{5}$ and tetrazine $\mathbf{6}$ structures. The final decision in favor of structure $\mathbf{5}$ is made by single crystal X-ray analysis, which was executed for the most stable pyrazolothiatriazines $\mathbf{5 k}, \mathbf{l}$. Structural parameters for compounds $\mathbf{5 k} \mathbf{k} \mathbf{l}$ are given in the Supplementary data and a view of compound 5k is depicted in Fig. $\mathbf{1}$ and for compound $\mathbf{5 1}$ is available from our preliminary study. ${ }^{17}$

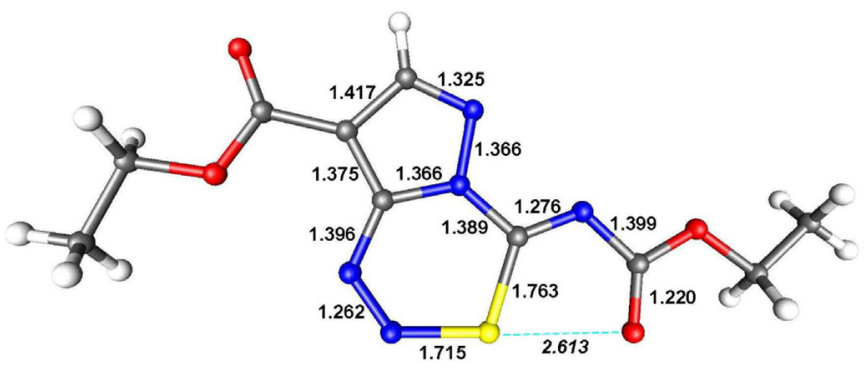

(a) Crystallographic data

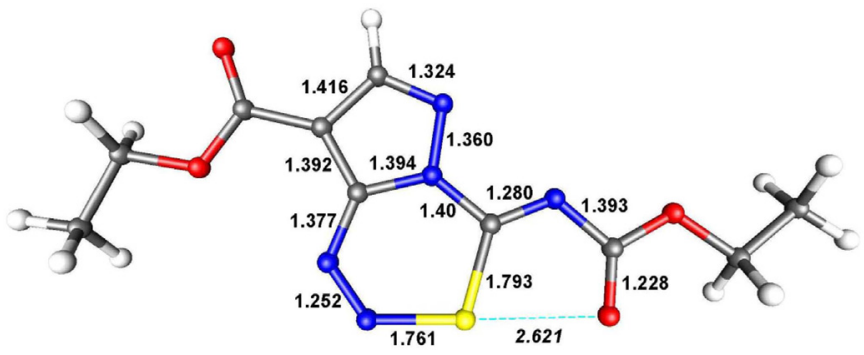

(b) B3LYP/6-31+G** optimized geometry

Fig. 1. Obtained geometry of ethyl 8-ethoxycarbonyl-iminopyrazolo[5,1-d][1,2,3,5] thiatriazine-4-carboxylate $\mathbf{5 k}$.
According to the X-ray diffraction data, molecules 5k,1 are in the crystalline form a nearly planar structure. The maximum deviation from the best plane through the heterocycle is $0.008(1) \AA$ for $\mathrm{N}^{5}$ in 5k and $-0.038(2) \AA$ for $\mathrm{C} 6$ in 51. The five- and six-membered rings in 51 make an angle of $1.68(8)^{\circ}$. Bond angles $\mathrm{N}_{2}-\mathrm{N}_{3}-\mathrm{O}_{12}$ are near to $180^{\circ}$. The configuration of the external imine substituent is $Z$ and the $\mathrm{S} 1 \cdots 017$ distance is $2.613(1) \AA$ in 5k and 2.496(1) $\AA$ in 51. This is in both cases shorter than the sum of the corresponding van der Waals radii (3.2 $\AA$ ), and in the case of $\mathbf{5 1}$ also shorter than the Huggins constant energy distance of $2.58 \AA,{ }^{26}$ indicating a degree of covalent bonding. Both short $\mathrm{O}-\mathrm{S}$ contacts and near linear arrangement of fragment $\mathrm{N}-\mathrm{S}-\mathrm{O}$ makes possible the overlapping of a nonbonded orbital located on the oxygen of the carbonyl group $\left(\mathrm{n}_{\mathrm{O}} \rightarrow \sigma^{*} \mathrm{~s}-\mathrm{N}\right){ }^{27}$

The study of so-called 'nonbonded S-O interactions' are of interest both in theoretical and experimental research ${ }^{27-30}$ due to its importance in different fields. For example, the consequence of the presence of this type of interaction in certain compounds could be the stabilization of isomers supporting a planar structure, that is, required to interact with some enzymes and exhibit biological activity. ${ }^{31}$ Thus, nonbonding sulfur-oxygen interaction can control the stereoselectivity of some reactions. ${ }^{32}$ Quite recently, the easiness of oxidative cyclizations of $\mathrm{N}$-acyl 2-arylhydrazonothioacetamides to 5 acylimino-2,5-dihydro-1,2,3-thiadiazoles was explained by the existence of very strong nonbonded $\mathrm{S}-\mathrm{O}$ interactions and the aromaticity of the reaction products. ${ }^{33}$

To evaluate these stabilizing $\mathrm{S}-\mathrm{O}$ interactions quantitatively, the difference of Gibbs energies for two conformations $(\Delta E)$ (See Table 2) were calculated at the B3LYP/6-31G* level of theory. These data confirm that structures $\mathbf{5}$ with hypervalent thiadiazole sulfur atom (conformation A) are more stable than the ones where nonbonded $\mathrm{S} \cdots \mathrm{O}$ through-space interaction are absent (conformation $\mathbf{B}$ ).

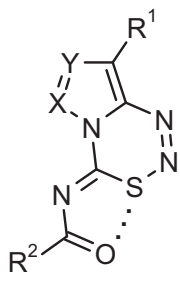

Conformation A<smiles>[R][Y]1c([Y])c2nns/c(=N/C([R])=O)n12</smiles>

Conformation B
Table 2

Quantum chemical descriptors calculated to describe the $\mathrm{S} \cdots \mathrm{O}$ interaction

\begin{tabular}{ccllllllll}
\hline & $\mathrm{n}(\mathrm{S} \cdots \mathrm{O})^{\mathrm{a}}$ & $\mathrm{E}(2)^{\mathrm{b}}$ & $\mathrm{r}(\mathrm{SO})^{\mathrm{c}}$ & $\alpha(\mathrm{N}-\mathrm{S}-\mathrm{O})^{\mathrm{d}}$ & $\chi^{\mathrm{e}}$ & $\rho(\mathrm{BCP})^{\mathrm{f}}$ & $\mathrm{RCP}^{\mathrm{g}}$ & $\Delta E^{\mathrm{h}}$ & $t^{\mathrm{i}}$ \\
\hline $\mathbf{5 k}$ & 0.0695 & 5.58 & 2.62 & 178.5 & 0.489 & $2.606 \cdot 10^{-2}$ & + & 3.006 & 16 \\
$\mathbf{5 1}$ & 0.0915 & 6.98 & 2.56 & 178.5 & 0.527 & $2.946 \cdot 10^{-2}$ & + & 5.023 & 3.5 \\
$\mathbf{5 0}$ & 0.0844 & 7.02 & 2.59 & 178.8 & 0.511 & $2.793 \cdot 10^{-2}$ & + & 3.894 & 6.0 \\
$\mathbf{5 u}$ & 0.0387 & 2.40 & 2.77 & 172.3 & 0.389 & $1.925 \cdot 10^{-2}+$ & - & -
\end{tabular}

${ }^{a}$ Wiberg bond indexes in the NAO basis (NBO, B3LYP/6-31+G**).

b The stabilization energy gained by donation from NBO of donor to NBO of acceptor, calculated with a help of second order perturbation theory in $\mathrm{kcal} / \mathrm{mol}$ (NBO, B3LYP/6-31+G**).

c $\mathrm{S}$... distance, in $\AA$ (B3LYP/6-31+G**).

d Bond angle $\mathrm{N}-\mathrm{S}-\mathrm{O}$, in ${ }^{\circ}$ (B3LYP/6-31+G**)

e Covalency index as introduced by F. Weinhold. ${ }^{29}$

f The electron density in $(3,-1)$ bond critical point in a.u. (AIM, B3LYP/6-31+G**). $\mathrm{g}$ ' + ' symbolizes that $(3,+1)$ ring critical point was located for $\mathrm{S}-\mathrm{C}-\mathrm{N}-\mathrm{C}-\mathrm{O}$ sequence (AIM, B3LYP/6-31+G**).

$\mathrm{h}$ The stabilization energy calculated as the difference in electronic energies between two conformers A and B and corrected with ZPE values, in $\mathrm{kcal} / \mathrm{mol}$ (B3LYP/6$\left.31+\mathrm{G}^{* *}\right)$.

i The reaction time, h. 
The benefit of stabilization, quantitatively expressed as an energy difference between two conformations, was decreasing in the series $\mathbf{5 l}>\mathbf{5 0}>\mathbf{5 k}$. It should be mentioned that two equal conformations $\mathbf{A}$ and $\mathbf{A}^{\prime}$ were found for $\mathbf{5 u}$ (See Supplementary data for 3D representations of located structures). As a result, no energy difference $\Delta E$ was calculated for $\mathbf{5 u}$ (Table 2). Analysis of the length differences for bonds $\mathrm{C}=\mathrm{O}, \mathrm{C}=\mathrm{N}$, and $\mathrm{C}-\mathrm{N}$ of conformations $\mathrm{A}$ and B calculated at the B3LYP/6-31G* level of theory for compounds $\mathbf{5 k}, \mathbf{l}, \mathbf{o}$ has shown that they are slightly distorted in conformation $\mathbf{A}$. The double bonds became longer and $\mathrm{C}-\mathrm{N}$ single bonds shorter in comparison with conformation B for $0.01-0.027 \AA$ (See Table 2).

Calculated $d_{\mathrm{s}-\mathrm{o}}$ distances were used to obtain the Weinhold covalence ratio factors $\chi^{29}$ for these compounds. Values were varying in a $0.389-0.527$ interval (See Table 2 ), suggesting that the strongest $\mathrm{S} \cdots \mathrm{O}$ interactions are to be found in $\mathbf{5 1}$ and $\mathbf{5 0 .}$

The expansion of the oxygen lone pair electron density to vacant $\sigma^{*}(\mathrm{~S}-\mathrm{N})$ orbital was studied within an NBO (Natural Bond Orbitals) framework $^{34}$ (See Fig. 2). The Wiberg bond indexes and electron population for the corresponding atoms were also calculated. Second order perturbation theory analysis of the Fock matrix in a NBO basis was applied to estimate the stabilization energy, $E(2)$ gained as a result of electron delocalization from one orbital to another (See Table 2). Correlating experimentally observed reaction time and calculated stabilization descriptors, one can see that stronger $S \cdots O$ interaction correlates with lower reaction time. For example, compound $\mathbf{5 1}$ reacts faster and has a higher Wiberg bond index $n$, energy of $n \rightarrow \sigma^{*}$ interaction $E(2)$, covalency ratio factor $\chi$, and energy stabilization $\Delta E$ comparing to compounds 50 and $\mathbf{5 k}$. Remarkably, the compound $\mathbf{5 u}$ bearing arylsulfonyl group at nitrogen atom that was not formed in reaction of diazo compounds $\mathbf{2}$ with phenylsulfonyl isocyanate, distinguished drastically from $\mathbf{5 k}, \mathbf{l}, \mathbf{o}$ in respect of all calculated characteristics (See Table 2). The existence of $\mathrm{S}$... O dative bond and formation of new cyclic fragment within the molecule were also confirmed in AIM (Atoms in Molecule) notations. ${ }^{35}$ The $(3,-1)$ bond critical points of $\rho$ for $S \cdots O$ bond and the $(3,+1)$ ring critical points for five-membered rings containing sulfur and oxygen atoms were located for all selected calculated structures (See Table 2). Thus, all quantum chemical descriptors, used to describe the $S \cdots O$ interaction, advocate that compounds $\mathbf{5}$ contain a pseudoheterocyclic oxathiazole ring fused to the 1,2,3,5-thiatriazine ring and thus are similar in this respect to the family of thiapentalenes. ${ }^{27}$ To the best of our knowledge, this is the first example of the existence of a relatively strong $\mathrm{S}-\mathrm{O}$ interaction, where sulfur belongs to a six-membered ring.

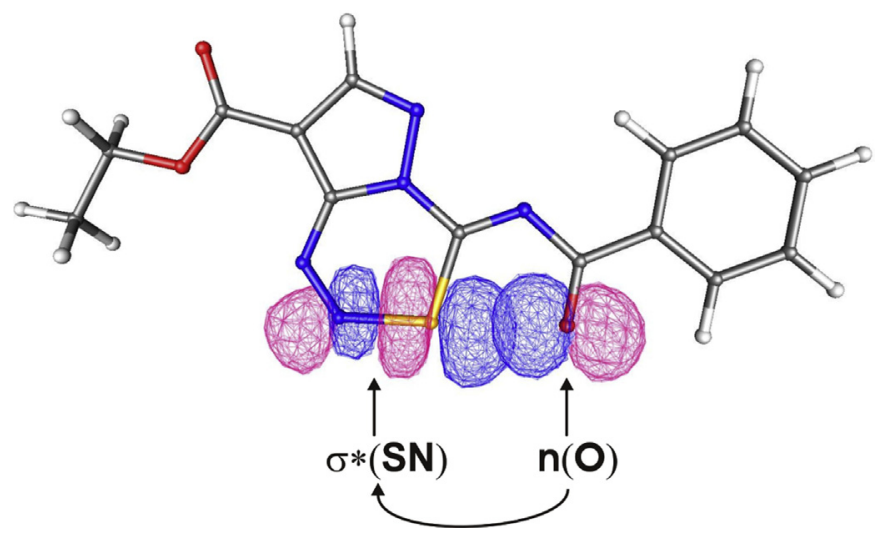

Fig. 2. $\mathrm{n}(\mathrm{O}) \rightarrow \sigma^{*}(\mathrm{SN})$ interaction shown in $\mathrm{NBO}$ orbitals (B3LYP/6-31+G** $\mathrm{G}^{* *}$ of compound $\mathbf{5 l}$.

This newly discovered reaction represents the first example of cycloaddition of diazoazoles to a $\mathrm{C}=\mathrm{S}$ bond. It is worth mentioning that 1,2,3,5-thiatriazines fused to any heterocycles were not known from the literature and examples of monocyclic 1,2,3,5-thiatriazines are limited to a very few compounds described in a single paper. ${ }^{36}$

The acyl substituent on the isothiocyanate led to a stabilization of the final product $\mathbf{5}$ due to an $S \cdots . O$ interaction, which is in agreement with both X-ray data for thiatriazines $\mathbf{5 k} \mathbf{1}$ and calcula-

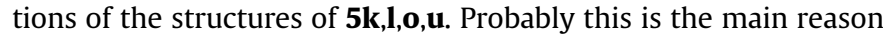
of the difference in the reactivity of acyl isothiocyanates and alkyl and aryl isothiocyanates in their reaction with diazoazoles and this may be the driving force for the reaction.

\section{Conclusions}

In summary, we have developed an efficient method for the synthesis of imidazo- and pyrazolo[5,4-b][1,2,3,5]thiatriazines based on cycloaddition reaction of diazoazoles with acyl isothiocyanates. The prepared compounds are shown by both X-ray data for thiatriazines $\mathbf{5 k}, \mathbf{1}$ and by calculations for the structures $\mathbf{5 k}, \mathbf{l}, \mathbf{o}$ to have relatively strong $\mathrm{S}-\mathrm{O}$ nonbonded interactions. These studies reveal that the introduction of an acyl group to the nitrogen atom of isothiocyanates is essential for the formation of the thiatriazine ring in the studied reactions with diazoazoles.

\section{Experimental section}

\subsection{General}

IR spectra were recorded on a Perkin Elmer 1600 Series FTIR in $\mathrm{KBr}$ pellets. The ${ }^{1} \mathrm{H}$ and ${ }^{13} \mathrm{C}$ NMR spectra were recorded in $\left[{ }^{2} \mathrm{H}_{6}\right]$ DMSO solution with Bruker WR-300 and Bruker DRX-400, 300 and $400 \mathrm{MHz}$ for ${ }^{1} \mathrm{H}, 75$ and $100 \mathrm{MHz}$ for ${ }^{13} \mathrm{C}$ using TMS as internal standard. X-ray diffraction measurements were made on a Bruker SMAART 6000 diffractometer equipped with CCD detector using CuK $\alpha$ radiation $(\lambda=1.54178 \AA)$.

\subsection{General procedure for the synthesis of the azolo[5,1-d] $[1,2,3,5]$ thiatriazines $(5 a-t)$}

The corresponding acyl isothiocyanate $4 \mathbf{a}-\mathbf{c}(1.0 \mathrm{mmol})$ in anhydrous ethyl acetate $(3 \mathrm{~mL})$ was added to a cooled solution of 5diazoazole $\mathbf{2 b}-\mathbf{j}(0.5 \mathrm{mmol})$ in anhydrous ethyl acetate $(5 \mathrm{~mL})$, in a dropwise manner at $-10^{\circ} \mathrm{C}$, in the dark. The mixture was stirred at room temperature until the compounds $\mathbf{2}$ according TLC analysis taken disappeared. Then, activated charcoal was added and the mixture was filtered. Then, the solvent was removed in vacuo (temperature $<40^{\circ} \mathrm{C}$ ). The residue was triturated with diethyl ether or hexane, collected, air-dried, and purified by flash chromatography with $\mathrm{CH}_{3} \mathrm{COOC}_{2} \mathrm{H}_{5} / \mathrm{CH}_{2} \mathrm{Cl}_{2}$ as the eluant to give $\mathbf{5 a}-\mathbf{t}$.

4.2.1 (Z)-Ethyl 4-(ethoxycarbonylimino)-4H-imidazo[5,1-d][1,2,3,5] thiatriazine-8-carboxylate (5a). Yield $0.12 \mathrm{~g}$ (79\%), mp 101-102 ${ }^{\circ} \mathrm{C}$; $\nu_{\max }(\mathrm{KBr}), \mathrm{cm}^{-1}: 1677.2,1728.6,2932.2,2980.0,3068.2,3128.1 ; \delta_{\mathrm{H}}$ (300.13 MHz, DMSO-d $\left.d_{6}, 300 \mathrm{~K}\right): 1.27\left(3 \mathrm{H}, \mathrm{t}, J 7.3 \mathrm{~Hz}, \mathrm{OCH}_{2} \mathrm{CH}_{3}\right), 1.35$ $\left(3 \mathrm{H}, \mathrm{t}, J 7.3 \mathrm{~Hz}, \mathrm{OCH}_{2} \mathrm{CH}_{3}\right), 4.29\left(2 \mathrm{H}, \mathrm{q}, J 7.3 \mathrm{~Hz}, \mathrm{OCH}_{2} \mathrm{CH}_{3}\right), 4.44(2 \mathrm{H}, \mathrm{q}, J$ $\left.7.3 \mathrm{~Hz}, \mathrm{OCH}_{2} \mathrm{CH}_{3}\right), 9.14(1 \mathrm{H}, \mathrm{s}, 6-\mathrm{H})$; $\delta_{\mathrm{C}}\left(75.4 \mathrm{MHz}, \mathrm{DMSO}-d_{6}, 300 \mathrm{~K}\right)$ : $13.9,14.1,61.5,63.6,131.5,134.3,134.6,158.1,160.0,160.1$. Calcd for $\mathrm{C}_{10} \mathrm{H}_{11} \mathrm{~N}_{5} \mathrm{O}_{4} \mathrm{~S}$ : C, 40.40; H, 3.73; N, 23.56; S, 10.79. Found: C, 40.43; H, 3.80; N, 23.54; S, 10.76.

4.2.2 (Z)-Ethyl 4-(benzoylimino)-4H-imidazo[5,1-d][1,2,3,5]thiatriazine-8-carboxylate (5b) ${ }^{17}$ and (Z)-Ethyl 8-(methylcarbamoyl)-4Himidazo[5,1-d][1,2,3,5]thiatriazin-4-ylidenecarbamate (5c). Yield $0.10 \mathrm{~g}(69 \%), \mathrm{mp} 115-116{ }^{\circ} \mathrm{C} ; \nu_{\max }(\mathrm{KBr}), \mathrm{cm}^{-1}: 1655,1680,2940$, 2980, 3100, 3120; $\delta_{\mathrm{H}}\left(400.13 \mathrm{MHz}\right.$, DMSO- $\left.d_{6}, 298 \mathrm{~K}\right): 1.30(3 \mathrm{H}, \mathrm{t}, J$ $\left.7.0 \mathrm{~Hz}, \mathrm{OCH}_{2} \mathrm{CH}_{3}\right), 2.86\left(3 \mathrm{H}, \mathrm{d}, J 4.7 \mathrm{~Hz}, \mathrm{NHCH}_{3}\right), 4.29(2 \mathrm{H}, \mathrm{q}, J 7.0 \mathrm{~Hz}$, $\left.\mathrm{OCH}_{2} \mathrm{CH}_{3}\right), 8.67\left(1 \mathrm{H}, \mathrm{q}, J 4.7 \mathrm{~Hz}, \mathrm{NHCH}_{3}\right), 9.15(1 \mathrm{H}, \mathrm{s}, 7-\mathrm{H}) ; \delta_{\mathrm{C}}$ (100.62 MHz, DMSO- $d_{6}, 298$ K): 13.9, 26.0, 63.4, 131.1, 132.6, 137.9, 
158.3, 159.6, 159.9. Calcd for $\mathrm{C}_{9} \mathrm{H}_{10} \mathrm{~N}_{6} \mathrm{O}_{3} \mathrm{~S}: \mathrm{C}, 38.30 ; \mathrm{H}, 3.57 ; \mathrm{N}$, 29.77; S, 11.36. Found: C, 38.40; H, 3.54; N, 29.82; S, 11.40.

4.2.3 (Z)-4-(Benzoylimino)-N-methyl-4H-imidazo[5,1-d][1,2,3,5]thiatriazine-8-carboxamide $(\mathbf{5 d})^{17}$ and $(Z)$-Ethyl 8-(pyrrolidine-1carbonyl)-4H-imidazo[5,1-d][1,2,3,5]thiatriazin-4-ylidenecarbamate (5e). Yield $0.11 \mathrm{~g}(70 \%), \mathrm{mp} 99-100^{\circ} \mathrm{C} ; \nu_{\max }(\mathrm{KBr}), \mathrm{cm}^{-1}: 1675,2880$, 2960, 2975, 3130; $\delta_{\mathrm{H}}\left(250.13 \mathrm{MHz}, \mathrm{DMSO}-d_{6}, 298 \mathrm{~K}\right): 1.30(3 \mathrm{H}, \mathrm{t}, J$ $\left.7.0 \mathrm{~Hz}, \mathrm{OCH}_{2} \mathrm{CH}_{3}\right), 1.85-1.93\left(4 \mathrm{H}, \mathrm{m}, 2 \mathrm{CH}_{2}\right), 3.51-3.58\left(4 \mathrm{H}, \mathrm{m}, 2 \mathrm{CH}_{2}\right)$, $4.28\left(2 \mathrm{H}, \mathrm{q}, J 7.0 \mathrm{~Hz}, \mathrm{OCH}_{2} \mathrm{CH}_{3}\right), 9.13(1 \mathrm{H}, \mathrm{s}, 6-\mathrm{H}) ; \delta_{\mathrm{C}}(100.62 \mathrm{MHz}$, DMSO- $\left.d_{6}, 298 \mathrm{~K}\right): 13.9,23.7,25.6,46.0,48.0,63.4,131.2,132.3,141.0$, 158.4,159.4, 160.0. Calcd for $\mathrm{C}_{12} \mathrm{H}_{14} \mathrm{~N}_{6} \mathrm{O}_{3} \mathrm{~S}$ : C, 44.71; $\mathrm{H}, 4.38 ; \mathrm{N}, 26.07$; S, 9.95. Found: C, 44.78; H, 4.40; N, 26.02; S, 10.02 .

4.2.4 (Z)-N-(8-(Pyrrolidine-1-carbonyl)-4H-imidazo[5,1-d][1,2,3,5] thiatriazin-4-ylidene)benzamide $(\mathbf{5} \boldsymbol{f})^{17}$ and (Z)-Ethyl 8-(piperidine-1carbonyl)-4H-imidazo[5,1-d][1,2,3,5]thiatriazin-4-ylidenecarbamate (5g). Yield $0.12 \mathrm{~g}(73 \%), \mathrm{mp} 103-104{ }^{\circ} \mathrm{C} ; \nu_{\max }(\mathrm{KBr}), \mathrm{cm}^{-1}: 1680$, 2860, 2930, 2960, 3130; $\delta_{\mathrm{H}}(400.13 \mathrm{MHz}$, DMSO-d 6 , $298 \mathrm{~K}): 1.30$ $\left(3 \mathrm{H}, \mathrm{t}, J 7.0 \mathrm{~Hz}, \mathrm{OCH}_{2} \mathrm{CH}_{3}\right), 1.48-1.47\left(2 \mathrm{H}, \mathrm{m}, \mathrm{CH}_{2}\right), 1.65-1.59(4 \mathrm{H}$, $\left.\mathrm{m}, 2 \mathrm{CH}_{2}\right), 3.41-3.38\left(2 \mathrm{H}, \mathrm{m}, \mathrm{CH}_{2}\right), 3.69-3.67\left(2 \mathrm{H}, \mathrm{m}, \mathrm{CH}_{2}\right), 4.28$ $\left(2 \mathrm{H}, \mathrm{q}, J 7.0 \mathrm{~Hz}, \mathrm{OCH}_{2} \mathrm{CH}_{3}\right), 9.12(1 \mathrm{H}, \mathrm{s}, 6-\mathrm{H}) ; \delta_{\mathrm{C}}(100.62 \mathrm{MHz}$, DMSO- $\left.d_{6}, 298 \mathrm{~K}\right):$ 13.9, 23.8, 25.3, 26.2, 42.3, 47.5, 63.4, 131.5, 132.0, 140.9, 158.3, 159.9, 160.0. Calcd for $\mathrm{C}_{13} \mathrm{H}_{16} \mathrm{~N}_{6} \mathrm{O}_{3} \mathrm{~S}$ : C, 46.42; H, 4.79; N, 24.98; S, 9.53. Found: C, 46.40; H, 4.82; N, 25.03; S, 9.50 .

4.2.5 (Z)-N-(8-(Piperidine-1-carbonyl)-4H-imidazo[5,1-d][1,2,3,5] thiatriazin-4-ylidene)-benzamide $(\mathbf{5 h})^{17}$ and (Z)-Ethyl 8-(morpholine-4-carbonyl)-4H-imidazo[5,1-d][1,2,3,5]thiatriazin-4ylidenecarbamate (5i). Yield $0.12 \mathrm{~g}(72 \%), \operatorname{mp} 96-98{ }^{\circ} \mathrm{C} ; \nu_{\max }(\mathrm{KBr})$, $\mathrm{cm}^{-1}: 1675,2850,2915,2975,3140 ; \delta_{\mathrm{H}}\left(400.13 \mathrm{MHz}, \mathrm{DMSO}-d_{6}\right.$, $298 \mathrm{~K}): 1.30\left(3 \mathrm{H}, \mathrm{t}, J 7.0 \mathrm{~Hz}, \mathrm{OCH}_{2} \mathrm{CH}_{3}\right), 3.51-3.50\left(2 \mathrm{H}, \mathrm{m}, \mathrm{CH}_{2}\right)$, 3.56-3.55 (2H, m, $\left.\mathrm{CH}_{2}\right), 3.72-3.70\left(4 \mathrm{H}, \mathrm{m}, 2 \mathrm{CH}_{2}\right), 4.28(2 \mathrm{H}, \mathrm{d}, J 7.0 \mathrm{~Hz}$, $\left.\mathrm{OCH}_{2} \mathrm{CH}_{3}\right), 9.14(1 \mathrm{H}, \mathrm{s}, 6-\mathrm{H}) ; \delta_{\mathrm{C}}\left(100.62 \mathrm{MHz}, \mathrm{DMSO}-d_{6}, 298 \mathrm{~K}\right): 13.9$, 42.1, 47.0, 63.4, 66.0, 66.4, 131.5, 132.4, 139.8, 158.2, 160.0, 160.1. Calcd for $\mathrm{C}_{12} \mathrm{H}_{14} \mathrm{~N}_{6} \mathrm{O}_{4} \mathrm{~S}$ : C, 42.60; $\mathrm{H}, 4.17 ; \mathrm{N}, 24.84 ; \mathrm{S}, 9.48$. Found: $\mathrm{C}$, 42.66; H, 4.20; N, 24.80; S, 9.44.

4.2.6 (Z)-N-(8-(Morpholine-4-carbonyl)-4H-imidazo[5,1-d][1,2,3,5] thiatriazin-4-ylidene)benzamide $(5 \mathbf{j})^{17}$ and (Z)-Ethyl 4-(ethoxycarbonylimino )-4H-pyrazolo[5,1-d][1,2,3,5]thiatriazine-8carboxylate (5k). Yield $0.11 \mathrm{~g}(72 \%), \mathrm{mp} 110-112{ }^{\circ} \mathrm{C} ; \nu_{\max }(\mathrm{KBr})$, $\mathrm{cm}^{-1}: 1666.0,1708.7,2910.5,2992.9,3110.2,3395.9 ; \delta_{\mathrm{H}}(300.13 \mathrm{MHz}$, DMSO- $\left.d_{6}, 300 \mathrm{~K}\right): 1.30\left(3 \mathrm{H}, \mathrm{t}, J 7.0 \mathrm{~Hz}, \mathrm{OCH}_{2} \mathrm{CH}_{3}\right), 1.36(3 \mathrm{H}, \mathrm{t}, J 7.0 \mathrm{~Hz}$, $\left.\mathrm{OCH}_{2} \mathrm{CH}_{3}\right), 4.28\left(2 \mathrm{H}, \mathrm{q}, J 7.0 \mathrm{~Hz}, \mathrm{OCH}_{2} \mathrm{CH}_{3}\right), 4.42(2 \mathrm{H}, \mathrm{q}, J 7.0 \mathrm{~Hz}$, $\left.\mathrm{OCH}_{2} \mathrm{CH}_{3}\right), 8.78(1 \mathrm{H}, \mathrm{s}, 7-\mathrm{H}) ; \delta_{\mathrm{C}}\left(75.4 \mathrm{MHz}, \mathrm{DMSO}-d_{6}, 300 \mathrm{~K}\right): 14.8$, $15.0,62.3,64.3,116.0,143.5,146.6,160.8,161.5,161.5$. Calcd for $\mathrm{C}_{10} \mathrm{H}_{11} \mathrm{~N}_{5} \mathrm{O}_{4} \mathrm{~S}: \mathrm{C}, 40.40 ; \mathrm{H}, 3.73 ; \mathrm{N}, 23.56 ; \mathrm{S}, 10.79$. Found: $\mathrm{C}, 40.32 ; \mathrm{H}$, 3.70; N, 23.63; S, 10.91 .

4.2.7 (Z)-Ethyl 4-(benzoylimino)-4H-pyrazolo[5,1-d][1,2,3,5]thiatriazine-8-carboxylate (5l) ${ }^{17}$ and (Z)-Ethyl 7-phenyl-4H-pyrazolo[5,1d] $1,2,3,5]$ thiatriazin-4-ylidenecarbamate (5m). Yield $0.13 \mathrm{~g}$ (87\%), $\mathrm{mp} 182-184{ }^{\circ} \mathrm{C} ; \nu_{\max }(\mathrm{KBr}), \mathrm{cm}^{-1}: 1710,1760,2350,2975,3140 ; \delta_{\mathrm{H}}$ (300.13 MHz, DMSO-d $d_{6}, 300 \mathrm{~K}$ ): 1.37 (3H, t, J 7.0 Hz, OCH $\mathrm{OCH}_{3}$ ), 4.30 $\left(2 \mathrm{H}, \mathrm{q}, J 7.0 \mathrm{~Hz}, \mathrm{OCH}_{2} \mathrm{CH}_{3}\right), 7.49-7.58\left(3 \mathrm{H}, \mathrm{m}, 3^{\prime}, 4^{\prime}, 5^{\prime}-\mathrm{H}\right), 8.15(2 \mathrm{H}, \mathrm{d}, J$ $\left.9.8 \mathrm{~Hz}, 2^{\prime}, 6^{\prime}-\mathrm{H}\right), 8.33(1 \mathrm{H}, \mathrm{s}, 8-\mathrm{H}) ; \delta_{\mathrm{C}}\left(75.4 \mathrm{MHz}, \mathrm{DMSO}-d_{6}, 300 \mathrm{~K}\right)$ : 14.0, 63.1, 110.1, 126.7, 129.1, 129.7, 129.2, 130.6, 145.9, 155.2, 160.8 . Calcd for $\mathrm{C}_{13} \mathrm{H}_{11} \mathrm{~N}_{5} \mathrm{O}_{2} \mathrm{~S}: \mathrm{C}, 51.82 ; \mathrm{H}, 3.68 ; \mathrm{N}, 23.24 ; \mathrm{S}, 10.64$. Found: $\mathrm{C}$, 51.88; H, 3.69; N, 23.07; S, 10.58.

4.2.8 (Z)-N-(7-Phenyl-4H-pyrazolo[5,1-d][1,2,3,5]thiatriazin-4ylidene)benzamide (5n). Yield $0.14 \mathrm{~g}(83 \%), \mathrm{mp} 196-198{ }^{\circ} \mathrm{C} ; \nu_{\max }$ $(\mathrm{KBr}), \mathrm{cm}^{-1}: 1745,2915,2325,2350,3115 ; \delta_{\mathrm{H}}(300.13 \mathrm{MHz}$, DMSO$\left.d_{6}, 300 \mathrm{~K}\right): 7.53-7.61\left(5 \mathrm{H}, \mathrm{m}, 3^{\prime}, 4^{\prime}, 5^{\prime}, 3^{\prime \prime}, 5^{\prime \prime}-\mathrm{H}\right), 7.66-7.69\left(1 \mathrm{H}, \mathrm{m}, 4^{\prime \prime}-\right.$
H), $8.22\left(2 \mathrm{H}, \mathrm{d}, J 7.9 \mathrm{~Hz}, 2^{\prime}, 6^{\prime}-\mathrm{H}\right), 8.34\left(2 \mathrm{H}, \mathrm{d}, J 7.0 \mathrm{~Hz}, 2^{\prime \prime}, 6^{\prime \prime}-\mathrm{H}\right), 8.39$ $(1 \mathrm{H}, \mathrm{s}, 8-\mathrm{H}) ; \delta_{\mathrm{C}}\left(75.4 \mathrm{MHz}, \mathrm{DMSO}-d_{6}, 300 \mathrm{~K}\right): 110.1,126.8,129.1$, 129.3, 129.4, 130.2, 130.6, 133.7, 134.3, 146.1, 155.2, 177.1. Calcd for $\mathrm{C}_{17} \mathrm{H}_{11} \mathrm{~N}_{5} \mathrm{OS}$ : C, 61.25; H, 3.33; N, 21.01; S, 9.62. Found: C, 61.29; H, 3.35; N, 21.06; S, 9.59 .

4.2 .9 (Z)-2,3,4,5-Tetrafluoro-N-(7-phenyl-4H-pyrazolo[5,1-d][1,2,3,5] thiatriazin-4-ylidene)benzamide (5o). Yield $0.16 \mathrm{~g}$ (78\%), mp $187-189{ }^{\circ} \mathrm{C} ; \nu_{\max }(\mathrm{KBr}), \mathrm{cm}^{-1}: 1600,1630,2925,3120,3410 ; \delta_{\mathrm{H}}$ (300.13 MHz, DMSO- $\left.d_{6}, 300 \mathrm{~K}\right): 7.58-7.63\left(3 \mathrm{H}, \mathrm{m}, 3^{\prime}, 4^{\prime}, 5^{\prime}-\mathrm{H}\right)$, $8.05-8.10\left(1 \mathrm{H}, \mathrm{m}, 6^{\prime \prime}-\mathrm{H}\right), 8.18-8.21\left(2 \mathrm{H}, \mathrm{m}, 2^{\prime}, 6^{\prime}-\mathrm{H}\right), 8.54(1 \mathrm{H}, \mathrm{s}, 8-$ $\mathrm{H}) ; \delta_{\mathrm{F}}\left(300.13 \mathrm{MHz}\right.$, DMSO- $\left.d_{6}\right)$ : $134.68 ; 137.57 ; 145.34 ; 153.31$. Calcd for $\mathrm{C}_{17} \mathrm{H}_{7} \mathrm{~F}_{4} \mathrm{~N}_{5} \mathrm{OS}$ : C, 50.38; H, 1.74; F 18.75; N, 17.28; S, 7.91. Found: C, 50.55; H, 1.86; F 18.52; N, 17.45; S, 7.85.

4.2.10 (Z)-Ethyl 7-(p-tolyl)-4H-pyrazolo[5,1-d][1,2,3,5]thiatriazin-4ylidenecarbamate (5p). Yield $0.15 \mathrm{~g}$ (96\%), mp $122-124{ }^{\circ} \mathrm{C} ; \nu_{\max }$ $(\mathrm{KBr}), \mathrm{cm}^{-1}: 1635,2320,2970,3110,3400 ; \delta_{\mathrm{H}}(300.13 \mathrm{MHz}$, DMSO$\left.d_{6}, 300 \mathrm{~K}\right): 1.31\left(3 \mathrm{H}, \mathrm{t}, J 7.0 \mathrm{~Hz}, \mathrm{OCH}_{2} \mathrm{CH}_{3}\right), 2.40\left(3 \mathrm{H}, \mathrm{s}, \mathrm{CH}_{3}\right), 4.28(2 \mathrm{H}$, q, $\left.J 7.0 \mathrm{~Hz}, \mathrm{OCH}_{2} \mathrm{CH}_{3}\right), 7.39\left(2 \mathrm{H}, \mathrm{d}, J 7.9 \mathrm{~Hz}, 3^{\prime}, 5^{\prime}-\mathrm{H}\right), 8.05(2 \mathrm{H}, \mathrm{d}, J$ $\left.7.9 \mathrm{~Hz}, 2^{\prime}, 6^{\prime}-\mathrm{H}\right), 8.41(1 \mathrm{H}, \mathrm{s}, 8-\mathrm{H}) ; \delta_{\mathrm{C}}\left(75.4 \mathrm{MHz}, \mathrm{DMSO}-d_{6}, 300 \mathrm{~K}\right)$ : 13.9, 21.0, 63.1, 109.9, 126.6, 126.9, 129.7, 140.5, 145.8, 155.2, 157.9, 160.8. Calcd for $\mathrm{C}_{14} \mathrm{H}_{13} \mathrm{~N}_{5} \mathrm{O}_{2} \mathrm{~S}$ : C, 53.32; $\mathrm{H}, 4.16 ; \mathrm{N}, 22.21 ; \mathrm{S}, 10.17$. Found: C, 53.38; H, 4.19; N, 22.33; S, 10.18 .

4.2.11 (Z)-N-(7-(p-Tolyl)-4H-pyrazolo[5,1-d][1,2,3,5]thiatriazin-4ylidene)benzamide (5q). Yield $0.17 \mathrm{~g}(98 \%), \mathrm{mp} 184-186{ }^{\circ} \mathrm{C} ; \nu_{\max }$ $(\mathrm{KBr}), \mathrm{cm}^{-1}: 1625,2350,3125,3450 ; \delta_{\mathrm{H}}\left(300.13 \mathrm{MHz}\right.$, DMSO- $d_{6}$, $300 \mathrm{~K}): 2.42\left(3 \mathrm{H}, \mathrm{s}, \mathrm{CH}_{3}\right), 7.43\left(2 \mathrm{H}, \mathrm{d}, J 7.9 \mathrm{~Hz}, 3^{\prime}, 5^{\prime}-\mathrm{H}\right), 7.63-7.67$ $\left(2 \mathrm{H}, \mathrm{m}, 3^{\prime \prime}, 5^{\prime \prime}-\mathrm{H}\right), 7.73-7.77\left(1 \mathrm{H}, \mathrm{m}, 4^{\prime \prime}-\mathrm{H}\right), 8.13\left(2 \mathrm{H}, \mathrm{d}, J 7.9 \mathrm{~Hz}, 2^{\prime}, 6^{\prime}-\right.$ $\mathrm{H}), 8.32\left(2 \mathrm{H}, \mathrm{d}, J 7.0 \mathrm{~Hz}, 2^{\prime \prime}, 6^{\prime \prime}-\mathrm{H}\right), 8.49(1 \mathrm{H}, \mathrm{s}, 8-\mathrm{H}) ; \delta_{\mathrm{C}}(75.4 \mathrm{MHz}$, DMSO-d6, $300 \mathrm{~K}): 21.0,109.8,126.7,127.0,129.0,129.8,130.2,133.7$, $134.2,140.5,146.0,155.3,157.5,177.1$. Calcd for $\mathrm{C}_{18} \mathrm{H}_{13} \mathrm{~N}_{5} \mathrm{OS}$ : C, 62.23; H, 3.77; N, 20.16; S, 9.23. Found: C, 62.29; H, 3.81; N, 20.30; S, 9.28 .

4.2.12 (Z)-2,3,4,5-Tetrafluoro-N-(7-p-tolyl-4H-pyrazolo[5,1-d][1,2,3,5] thiatriazin-4-ylidene)-benzamide (5r). Yield $0.17 \mathrm{~g}$ (83\%), $\mathrm{mp}$ $158-160{ }^{\circ} \mathrm{C}, \nu_{\max }(\mathrm{KBr}), \mathrm{cm}^{-1}: 1620,2920,2950,3115,3400 ; \delta_{\mathrm{H}}$ (300.13 MHz, DMSO-d $\left.d_{6}, 300 \mathrm{~K}\right): 2.44\left(3 \mathrm{H}, \mathrm{s}, \mathrm{CH}_{3}\right), 7.35(2 \mathrm{H}, \mathrm{d}, J 8.0 \mathrm{~Hz}$, $\left.3^{\prime}, 5^{\prime}-\mathrm{H}\right), 8.08\left(2 \mathrm{H}, \mathrm{d}, J 8.0 \mathrm{~Hz}, 2^{\prime}, 6^{\prime}-\mathrm{H}\right), 8.10-8.18\left(1 \mathrm{H}, \mathrm{m}, 2^{\prime \prime}-\mathrm{H}\right), 8.34$ $(1 \mathrm{H}, \mathrm{s}, 8-\mathrm{H}), \delta_{\mathrm{F}}\left(300.13 \mathrm{MHz}\right.$, DMSO- $\left.d_{6}\right): 134.75 ; 137.62 ; 145.42$; 153.35; $\delta_{\mathrm{C}}\left(75.4 \mathrm{MHz}\right.$, DMSO- $d_{6}, 300 \mathrm{~K}$ ): 21.6, 99.9, 109.9, 114.4, 114.6, 118.5, 126.5, 127.1, 130.0, 141.7, 145.6, 146.2, 157.1, 158.4, 180.4. Calcd for $\mathrm{C}_{18} \mathrm{H}_{9} \mathrm{~F}_{4} \mathrm{~N}_{5} \mathrm{OS}$ : C, 51.55; H, 2.16; F 18.12; N, 16.70; S, 7.65. Found: C, 51.48; H, 2.08; F 18.32; N, 16.79; S, 7.56.

4.2.13 (Z)-Ethyl 7-(4-methoxyphenyl)-4H-pyrazolo[5,1-d][1,2,3,5] thiatriazin-4-ylidenecarbamate (5s). Yield $0.12 \mathrm{~g}$ (70\%), mp 144-146 ${ }^{\circ} \mathrm{C} ; \nu_{\max }(\mathrm{KBr}), \mathrm{cm}^{-1}: 1645,2340,2975,3125,3450 ; \delta_{\mathrm{H}}$ (300.13 MHz, DMSO- $\left.d_{6}, 300 \mathrm{~K}\right): 1.37\left(3 \mathrm{H}, \mathrm{t}, J \mathrm{~J} .0 \mathrm{~Hz}, \mathrm{OCH}_{2} \mathrm{CH}_{3}\right), 3.87$ $\left(3 \mathrm{H}, \mathrm{s}, \mathrm{OCH}_{3}\right), 4.29\left(2 \mathrm{H}, \mathrm{q}, J 7.0 \mathrm{~Hz}, \mathrm{OCH}_{2} \mathrm{CH}_{3}\right), 7.05(2 \mathrm{H}, \mathrm{d}, J 8.9 \mathrm{~Hz}$, $\left.3^{\prime}, 5^{\prime}-\mathrm{H}\right), 8.08\left(2 \mathrm{H}, \mathrm{d}, J 8.9 \mathrm{~Hz}, 2^{\prime}, 6^{\prime}-\mathrm{H}\right), 8.26(1 \mathrm{H}, \mathrm{s}, 8-\mathrm{H}) ; \delta_{\mathrm{C}}$ (75.4 MHz, DMSO-d $\left.d_{6}, 300 \mathrm{~K}\right): 14.8,56.2,63.9,110.6,115.5,122.9$, 122.9, 129.2, 129.2, 146.7, 156.0, 162.0. Calcd for $\mathrm{C}_{14} \mathrm{H}_{13} \mathrm{~N}_{5} \mathrm{O}_{3} \mathrm{~S}$ : C, 50.75; H, 3.95; N, 21.14; S, 9.68. Found: C, 50.86; H, 4.02; N, 20.98; S, 9.59 .

4.2.14 (Z)-N-(7-(4'-Methoxyphenyl)-4H-pyrazolo[5,1-d][1,2,3,5]thiatriazin-4-ylidene)-benzamide (5t). Yield $0.16 \mathrm{~g}$ (89\%), mp $160-162{ }^{\circ} \mathrm{C} ; \nu_{\max }(\mathrm{KBr}), \mathrm{cm}^{-1}: 1620,2840,2950,3115,3450 ; \delta_{\mathrm{H}}$ (300.13 MHz, DMSO-d $\left.d_{6}, 300 \mathrm{~K}\right): 3.87\left(3 \mathrm{H}, \mathrm{s}, \mathrm{OCH}_{3}\right), 7.16(2 \mathrm{H}, \mathrm{d}, J$ $\left.8.9 \mathrm{~Hz}, 3^{\prime}, 5^{\prime}-\mathrm{H}\right), 7.60-7.66\left(2 \mathrm{H}, \mathrm{m}, 3^{\prime \prime}, 5^{\prime \prime}-\mathrm{H}\right), 7.71-7.74\left(1 \mathrm{H}, \mathrm{m}, 4^{\prime \prime}\right)$, $8.17\left(2 \mathrm{H}, \mathrm{d}, J 8.9 \mathrm{~Hz}, 2^{\prime}, 6^{\prime}-\mathrm{H}\right), 8.31\left(2 \mathrm{H}, \mathrm{d}, J 7.2 \mathrm{~Hz}, 2^{\prime \prime}, 6^{\prime \prime}-\mathrm{H}\right), 8.43$ $(1 \mathrm{H}, \mathrm{s}, 8-\mathrm{H}) ; \delta_{\mathrm{C}}\left(75.4 \mathrm{MHz}\right.$, DMSO- $\left.d_{6}, 300 \mathrm{~K}\right): 55.3,109.6,114.6$, $122.1,128.4,128.9,130.1,133.7,134.2,145.9,155.1,157.3,161.2$, 
177.1. Calcd for $\mathrm{C}_{18} \mathrm{H}_{13} \mathrm{~N}_{5} \mathrm{O}_{2} \mathrm{~S}$ : C, 59.49; $\mathrm{H}, 3.61$; N, 19.27; S, 8.82. Found: C, 59.52; H, 3.63; N, 19.36; S, 8.88.

\section{X-ray diffraction study of $5 k$}

Crystals were grown from ethyl acetate. All measurements were made on a Bruker SMART 6000 diffractometer equipped with a CCD detector using $\mathrm{CuK} \alpha$ radiation $(\lambda=1.54178 \AA$ ). The crystal system of compound 5k $\left(\mathrm{C}_{10} \mathrm{H}_{11} \mathrm{~N}_{5} \mathrm{O}_{4} \mathrm{~S}, M=297.30\right)$ is orthorhombic, space group Pbca, $a=8.6546(2), b=7.8213(2), c=37.2599(8) \AA, Z=8$, $V=2522.13(10) \AA 3, D_{\mathrm{c}}=1.566 \mathrm{~g} / \mathrm{cm}^{3}, F(000)=1232$, crystal size: $0.10 \times 0.60 \times 0.60 \mathrm{~mm}, \mu(\mathrm{CuK} \alpha)=2.524 \mathrm{~mm}^{-1}, T=373 \mathrm{~K}, 11,654 \mathrm{re}-$ flections collected, 2356 unique reflections, $R_{\mathrm{int}}=0.135$. Final $R$ indices: $R_{1}=0.0566$ for 2123 reflections with $I>2 \sigma(I)$ and $R_{1}=0.0500$, $w R_{2}=0.1522$ for all data. Crystallographic data (excluding structure factors) for this structure have been deposited with the Cambridge Crystallographic Data Centre. Copies of the data can be obtained free of charge on application to CCDC, 12 Union Road, Cambridge CB2 1EZ, UK (fax: +44-1223-336033; e-mail: deposit@ccdc.cam.ac.uk).

\section{Computational details}

All calculations were performed by G09 suit. ${ }^{37}$ Structures were initially optimized at B3LYP/6-31+ $\mathrm{G}^{* *}$ level of theory. To prove the true character of located minima, Hessian was calculated. No imaginary frequency modes were found for all structures. NBO analysis was done at the same level by NBO 3.0 module implemented in G09.38 Obtained B3LYP/6-31+ $\mathrm{G}^{* *}$ densities were analyzed by AIM scheme with a help of AIMAll software. ${ }^{39}$ gOpenMol ${ }^{40,41}$ and Gabedit ${ }^{42}$ software were used for visualization of results.

\section{Acknowledgements}

V.A.B. thanks Russian Foundation for Basic Research (grants no. 10-03-00897-a). W.D. thanks the FWO-Vlaanderen, the Ministerie voor Wetenschapsbeleid and the KU Leuven for continuing financial support. J.O.S. personally thanks Prof. Arvi Rauk (University of Calgary, Canada) for assistance. J.O.S. also thanks Compute Canada - Calcul Canada and Western Canada Research Grid for provided computational resources. J.O.S. thanks Russian Foundation for Basic Research (grants no. 12-03-31574 mol_a).

\section{Supplementary data}

Supplementary data related to this article can be found at http:// dx.doi.org/10.1016/j.tet.2013.06.062.

\section{References and notes}

1. Zollinger, H. Diazo Chemistry. 2. Aliphatic, Inorganic and Organometallic Compounds; VHS, Weinheim: New York, NY; Basel, Switzerland; Cambridge, UK; Tokyo, Japan, 1995; p 522.
2. Gioiello, A.; Khamidullina, A.; Fulco, M. C.; Venturoni, F.; Zlotsky, S.; Pellicciari, R. Tetrahedron Lett. 2009, 50, 5978.

3. Tuktarov, A. R.; Khuzin, A. A.; Korolev, V. V.; Dzhemilev, U. M. Russ. J. Org. Chem 2012, 48, 99.

4. Bakulev, V. A.; Dehaen, W. Heterocyclic Compounds. The Chemistry of 1,2,3thiadiazoles; John Wiley \& Sons: USA, 2004; Vol. 62, pp 241.

5. Shafran, Y. M.; Bakulev, V. A.; Mokrushin, V. S.; Alekseev, S. G. Chem. Heterocycl. Compd. 1984, 20, 1038.

6. Bakulev, V. A. Russ. Chem. Rev. 1995, 64, 99

7. Fabian, W. M. F.; Bakulev, V. A.; Kappe, C. O. J. Org. Chem. 1998, 63, 5801

8. Fabian, W. M. F.; Bakulev, V. A.; Janoschek, R. J. Mol. Struct. THEOCHEM 2007, 821 89.

9. Magee, W. L.; Rao, C. B.; Glinka, J.; Hui, H.; Amick, T. J.; Fiscus, D.; Kakodkar, S.; Nair, M.; Shechter, H. J. Org. Chem. 1987, 52, 5538.

10. Diana, P.; Barraja, P.; Lauria, A.; Montalbano, A.; Almerico, A. M.; Dattolo, G.; Cirrincione, G. Bioorg. Med. Chem. 2003, 11, 2371.

11. Wang, Y.; Stevens, M. F. G.; Chan, T.-M.; DiBenedetto, D.; Ding, Z.-X.; Gala, D.; Hou, D.; Kugelman, M.; Leong, W.; Kuo, S.-C.; Mas, J. L.; Schumacher, D. P.; Schutts, B. P.; Smith, L.; Zhan, Z.-Y. J. J. Org. Chem. 1997, 62, 7288.

12. Ege, G.; Gilbert, K.; Maurer, K. Chem. Ber. 1987, 120, 1375.

13. Xu, X.; Stockhammer, F.; Schmitt, A.; Casalegno-Garduno, R.; Enders, A.; Mani, J.; Classen, C. F.; Linnebacher, M.; Freund, M.; Schmitt, M. Int. J. Oncol. 2012, 40, 764

14. Pietanza, M. C.; Kadota, K.; Huberman, K.: Sima, C. S.; Fiore, J. J.: Sumner, D. K. Travis, W. D.; Heguy, A.; Ginsberg, M. S.; Holodny, A. I.; Chan, T. A.; Rizvi, N. A.; Azzoli, C. G.; Riely, G. J.; Kris, M. G.; Lee, M. K. Clin. Cancer Res. 2012, 18, 1138.

15. Newlands, E. S.; Stevens, M. F. G.; Wedge, S. R.; Wheelhouse, R. T.; Brock, C Cancer Treat. Rep. 1997, 23, 35.

16. Wang, Y.; Lowe, P. R.; Thomson, W. T.; Clark, J.; Stevens, M. F. G. Chem. Commun 1997, 363.

17. Sadchikova, E. V.; Bakulev, V. A.; Dehaen, W.; Van Hecke, K.; Robeyns, K.; Van Meervelt, L.; Mokrushin, V. S.; Padwa, A. Synlett 2004, 2037.

18. Deeb, A.; Kotb, M. Heterocycles 2004, 63, 1143.

19. Subbotina, J. O.; Sadchikova, E. V.; Bakulev, V. A.; Fabian, W. M. F.; Herges, R. Int J. Quantum Chem. 2007, 107, 2479.

20. Sadchikova, E. V.; Mokrushin, V. S. Russ. Chem. Bull. 2006, 55, 1255.

21. Shchegol'kov, E. V.; Sadchikova, E. V.; Burgart, Y. V.; Saloutin, V. I. Russ. Chem. Bull. 2008, 56, 599.

22. Shchegol'kov, E. V.; Sadchikova, E. V.; Burgart, Y. V.; Saloutin, V. I. Russ. J. Org. Chem. 2009, 45, 572.

23. Sadchikova, E. V.; Mokrushin, V. S. Russ. Chem. Bull. 2003, 52, 1600.

24. L'abbé, G.; Francis, A.; Dehaen, W.; Bosman, J. Bull. Soc. Chim. Belg. 1996, 105 253.

25. L’abbé, G.; Francis, A.; Dehaen, W. J. Chem. Soc., Perkin Trans. 1 1996, 1349.

26. Huggins, M. L. J. Am. Chem. Soc. 1953, 75, 4126.

27. Minkin, V. I.; Minyaev, R. M. Chem. Rev. 2001, 101, 1247.

28. Poater, J.; Casanavas, J.; Sola, M.; Aleman, C. J. Phys. Chem. 2010, 114, 1023

29. Reed, A. E.; Curtiss, L. A.; Weinhold, F. Chem. Rev. 1988, 88, 899.

30. Peña-Hueso, A.; Téllez, F.; Vieto-Peña, R.; Esquivel, R. O.; Esparza-Ruiz, A.; Ramos-García, I.; Contreras, R.; Barba-Behrens, N.; Flores-Parra, A. J. Mol. Struct. 2010, 984, 409 .

31. Tajima, H.; Honda, T.; Kawashima, K.; Sasabubuchi, Y.; Yamamoto, M.; Ban, M.; Okamoto, K.; Inoue, K.; Inaba, T.; Takeno, Y.; Aono, H. Bioorg. Med. Chem. 2010 20,7234 .

32. Gonzalez, F. V.; Jain, A.; Rodriguez, S.; Saez, J. A.; Vicent, C.; Peris, G. J. Org. Chem. 2010, 75, 5888.

33. Belskaya, N. P.; Subbotina, J. O.; Bolgova, A. I.; Lugovik, K. I.; Slepukhin, P. A. Bakulev, V. A. Tetrahedron 2013, in press (TET-D-12-02254R1).

34. Weinhold, F.; Landis, C. R. Discovering Chemistry with Natural Bond Orbitals; Wiley-VCH: Hoboken, NJ, 2012; p 319.

35. Bader, R. F. W. Atoms in Molecules: a Quantum Theory; Oxford University Press: USA, 1994.

36. Barluenga, J.; Tomás, M.; Ballesteros, A.; López, L. A. Synthesis 1995, 985.

37. Gaussian 09, Revision C.01; Gaussian: Wallingford, CT, 2009.

38. NBO, Version 3.1; Glendening E. D.; Reed A. E.; Carpenter J. E.; Weinhold F.

39. AIMAll, Version 13.02.26; TK Gristmill Software: Overland Park, KS, USA, 2012.

40. Laaksonen, L. J. Mol. Graphics Modell. 1992, 10, 33.

41. Bergman, D. L.; Laaksonen, L.; Laaksonen, A. J. Mol. Graphics Modell. 1997, 15, 301 42. Allouche, A.-R. J. Comput. Chem. 2011, 32, 174 